\title{
A precision medicine classification for treatment of acute myeloid leukemia in older patients
}

Alice S. Mims ${ }^{1 *} \mathbb{D}$, Jessica Kohlschmidt ${ }^{1,2,3}$, Uma Borate ${ }^{1}$, James S. Blachly ${ }^{1}$, Shelley Orwick', Ann-Kathrin Eisfeld ${ }^{1,3}$, Dimitrios Papaioannou', Deedra Nicolet ${ }^{1,2,3}$, Krzysztof Mrózek $^{1,3}$, Eytan Stein ${ }^{4}$, Bhavana Bhatnagar ${ }^{1}$, Richard M. Stone ${ }^{5}$, Jonathan E. Kolitz ${ }^{6}$, Eunice S. Wang ${ }^{7}$, Bayard L. Powell ${ }^{8}$, Amy Burd ${ }^{9}$, Ross L. Levine ${ }^{4}$, Brian J. Druker ${ }^{10}$, Clara D. Bloomfield ${ }^{1 \wedge}$ and John C. Byrd ${ }^{1,3,11^{*}}$

\begin{abstract}
Background: Older patients ( $\geq 60$ years) with acute myeloid leukemia (AML) often have multiple, sequentially acquired, somatic mutations that drive leukemogenesis and are associated with poor outcome. Beat AML is a Leukemia and Lymphoma Society-sponsored, multicenter umbrella study that algorithmically segregates AML patients based upon cytogenetic and dominant molecular abnormalities (variant allele frequencies (VAF) $\geq 0.2$ ) into different cohorts to select for targeted therapies. During the conception of the Beat AML design, a historical dataset was needed to help in the design of the genomic algorithm for patient assignment and serve as the basis for the statistical design of individual genomic treatment substudies for the Beat AML study.

Methods: We classified 563 newly diagnosed older AML patients treated with standard intensive chemotherapy on trials conducted by Cancer and Leukemia Group B based on the same genomic algorithm and assessed clinical outcomes.

Results: Our classification identified core-binding factor and NPM1-mutated/FLT3-ITD-negative groups as having the best outcomes, with 30-day early death (ED) rates of 0 and 20\%, respectively, and median overall survival (OS) of $>1$ year and 3 -year OS rates of $\geq 20 \%$. All other genomic groups had ED rates of $17-42 \%$, median $O S \leq 1$ year and 3 -year OS rates of $\leq 15 \%$.
\end{abstract}

Conclusions: By classifying patients through this genomic algorithm, outcomes were poor and not unexpected from a non-algorithmic, non-dominant VAF approach. The exception is 30-day ED rate typically is not available for intensive induction for individual genomic groups and therefore difficult to compare outcomes with targeted therapeutics. This Alliance data supported the use of this algorithm for patient assignment at the initiation of the Beat AML study. This outcome data was also used for statistical design for Beat AML substudies for individual genomic groups to determine goals for improvement from intensive induction and hopefully lead to more rapid approval of new therapies.

\footnotetext{
*Correspondence: alice.mims@osumc.edu; John.Byrd@osumc.edu

${ }^{1}$ The Ohio State University Comprehensive Cancer Center, 320 West 10th

Avenue, Starling Loving Hall B302, Columbus, OH 43210, USA

Full list of author information is available at the end of the article

Clara D. Bloomfield: Deceased.
}

(c) The Author(s) 2021. Open Access This article is licensed under a Creative Commons Attribution 4.0 International License, which permits use, sharing, adaptation, distribution and reproduction in any medium or format, as long as you give appropriate credit to the original author(s) and the source, provide a link to the Creative Commons licence, and indicate if changes were made. The images or other third party material in this article are included in the article's Creative Commons licence, unless indicated otherwise in a credit line to the material. If material is not included in the article's Creative Commons licence and your intended use is not permitted by statutory regulation or exceeds the permitted use, you will need to obtain permission directly from the copyright holder. To view a copy of this licence, visit http://creativecommons.org/licenses/by/4.0/. The Creative Commons Public Domain Dedication waiver (http://creativeco mmons.org/publicdomain/zero/1.0/) applies to the data made available in this article, unless otherwise stated in a credit line to the data. 
Trial registration ClinicalTrials.gov Identifiers: NCT00048958 (CALGB 8461), NCT00900224 (CALGB 20202), NCT00003190 (CALGB 9720), NCT00085124 (CALGB 10201), NCT00742625 (CALGB 10502), NCT01420926 (CALGB 11002), NCT00039377 (CALGB 10801), and NCT01253070 (CALGB 11001).

Keywords: Acute myeloid leukemia, Mutation, Cytogenetics, Precision medicine, Outcome

\section{Background}

Acute myeloid leukemia (AML) is not a single entity but a multitude of diseases that differ with regard to pretreatment genetic features including cytogenetics and gene mutations [1-3]. Despite this disease heterogeneity, initial AML treatment approaches have been essentially the same for the past forty years, with patients either receiving intensive induction approaches (i.e., $7+3$ ) or palliative treatment including hypomethylating agents (HMA), subcutaneous cytarabine, supportive care, or hospice care. Over the past few years, numerous new agents have been added to the treatment arsenal of AML, including venetoclax combined with HMA or subcutaneous cytarabine, IDH1,IDH2, and FLT3 inhibitors, liposomal daunorubicin/cytarabine, gemtuzumab ozogamicin, and glasdegib combined with subcutaneous cytarabine [4-13]. In the upfront setting, venetoclax, glasdegib, ivosidenib, and liposomal daunorubicin/cytarabine are approved by the Food and Drug Administration for certain older patient populations or for patients with comorbidities that prevent them from tolerating intensive induction therapy. Although these treatments lead to improved outcomes, including increased complete remission (CR) rates, diseasefree survival (DFS), and overall survival (OS) for some AML patient populations, currently none of these therapies are considered curative unless the patients are able to undergo allogeneic stem cell transplantation in initial CR.

It is well known that older AML patients (aged $\geq 60$ years) have worse outcomes than younger patients, but the reasons for this are not entirely clear. Some contributing factors include higher incidence of high-risk cytogenetic and molecular genetic features, secondary or therapy-related AML, and comorbidities that limit more intensive treatment approaches including allogeneic stem cell transplantation [14]. However, even among patients with favorable-risk features such as core-binding factor (CBF) or NPM1 + /FLT3-ITDmutated AML who are able to tolerate and undergo intensive chemotherapy, older patients have worse outcomes compared with younger patients with these same genetic characteristics [15-17]. Vasu et al. showed that a 10-year DFS rate of older AML patients treated with intensive induction who were not able to receive allogeneic transplantation in first CR was 2.4\% [18].
In the era of high throughput sequencing (HTS) and the availability of targeted therapies, the question remains whether an individualized treatment approach based on the results of genetic tests performed at the time of diagnosis could improve the currently poor outcomes of older AML patients. The Leukemia and Lymphoma Society (LLS) has sought to answer this question through the Beat AML Master Study. Gene mutation analysis using HTS, cytogenetic analysis, and polymerase chain reaction (PCR)-based analysis for internal tandem duplication of the FLT3 gene (FLT3-ITD) are performed at the time of diagnosis in older patients with AML in a comprehensive and timely manner. Patients are then assigned to more individualized therapy based on the presence of cytogenetic and/or mutational drivers detected in the patients' leukemic clones by inferred variant allele frequency (VAF) [19]. However, to determine whether this approach constitutes improvement upon existing standard of care, it was necessary to have a historical perspective on particular genetic groups of older AML patients and their actual outcomes. This information allowed for study planning relative to a null hypothesis for outcome expectation in specific molecular/cytogenetic groups and provide a reference for regulatory agencies when evaluating new therapies relevant to these groups.

We analyzed data from 563 older newly diagnosed de novo AML patients treated on the Cancer and Leukemia Group B (CALGB, now part of the Alliance for Clinical Trials in Oncology) trials and retrospectively assigned them to several genetic groups based on an algorithm that incorporates targetable cytogenetic abnormalities and mutational drivers with high VAF. We aimed to determine 1) whether this algorithmic approach would lead to a genetic group assignment in the majority of patients and 2) the outcomes of patients assigned to each of the genetic groups to serve as a benchmark and allow comparisons with the results of treatment with new therapeutic agents.

\section{Methods}

\section{Patients, treatment, and cytogenetic studies}

We analyzed 563 adults $\geq 60$ years of age with newly diagnosed de novo AML (excluding acute promyelocytic leukemia) whose pretreatment bone marrow (BM) or blood samples underwent HTS analysis [20]. Patients who underwent allogeneic transplantation in first 
complete remission $(\mathrm{CR})$ were excluded as per required for the eligibility of the CALGB/Alliance protocols. HTS analysis was not performed in all patients with CBF AML because this subtype of AML represents an already recognized, curable entity and is at the top of the LLS prioritization schema. The patients were treated on CALGB trials which included a range of time from 1984 to 2013 with all receiving standard intensive treatment (Table 1 and further details in the Additional file 1) [21-30]. As patients on the RATIFY study (CALBG 10603) were eligible only from ages 18 to 59 , there are not any patients included in our analysis who received midostaurin as part of their chemotherapy regimen. All patients were considered for outcome analyses including those who suffered early death (ED), defined as death within 30 days after starting therapy irrespective of cause. Cytogenetic analyses of pretreatment $\mathrm{BM}$ and/or blood samples were performed by institutional CALGB/Alliance-approved laboratories. The results were confirmed by central karyotype review [31]. Patients provided written informed consent to participate in companion protocols CALGB 8461 (cytogenetic studies), CALGB 9665 (leukemia tissue bank), and CALGB 20,202 (molecular studies), which involved collection of pretreatment BM and blood samples. Treatment protocols were in accordance with the Declaration of Helsinki and approved by the institutional review boards at each center, and all patients provided written informed consent.

\section{Molecular analyses}

Mononuclear cells were enriched through FicollHypaque gradient centrifugation and cryopreserved until use. Genomic DNA was extracted using the DNeasy Blood and Tissue Kit (QIAGEN, Hilden, Germany). The mutational status of 81 protein-coding genes was determined centrally at The Ohio State University by targeted amplicon sequencing using two different gene panels on the MiSeq platform (Illumina, San Diego, CA; see Additional file 1 for details). MuCor was used for integrative data analysis [32]. Details about the variant calling are outlined in the Additional file 1. In addition to the 81 genes assessed by HTS, testing for CEBPA mutations was performed as previously described, thus resulting in mutational status of 82 genes being assessed in our study [33]. Only patients with biallelic CEBPA mutations were considered as mutated [2]. The presence or absence of FLT3-ITD, as well as quantification of the FLT3-ITD to FLT3 wild-type allelic ratio, was determined as previously described [34].

\section{Genetic algorithm/assignment}

This precision medicine-based stratification of AML patients was initially designed in 2015 and took into consideration "assignment to curative therapy with 7 and 3" for known responsive groups [i.e., CBF AML and NPM1-mutated/FLT3-ITD-negative (NPM1m/FLT3ITD-) patients] followed by genetic groups where high rationale therapeutic options were or soon would be available (KMT2A-rearranged, $I D H 2 \mathrm{~m}, I D H 1 \mathrm{~m})$. These groups were first followed by high-risk genetic/cytogenetic groups which could confound prognostic impact of other gene mutations and typically lack other common co-mutations (TP53m and complex karyotype with wild-type TP53), next followed by FLT3-mutated [including both FLT3-ITD and mutations in the tyrosine kinase domain of the FLT3 gene (FLT3-TKD)], then followed by the hypermethylation group [encompassing patients with TET2m [35, 36] or WT1m [37]], and then the markernegative group. The following priority schema (in order from highest to lowest) was used for the treatment assignment algorithm: CBF AML (CBF); NPM1m/FLT3ITD-; 11q23/KMT2A-rearranged (KMT2A); IDH2 mutated (IDH2m); IDH1 mutated (IDH1m); TP53 mutated (TP53m); complex karyotype/TP53 wild-type (complex karyotype/TP53wt); FLT3-ITD (both high and low allelic ratios included) or FLT3-TKD (FLT3m); WT1 mutated or TET2 mutated (WT1m or TET2m); and marker-negative group (i.e., all other karyotypes and mutations that did not occur as co-mutations and were not included in the aforementioned grouping) (Fig. 1). The presence of a clonal cytogenetic aberration, FLT3ITD allelic ratio of $\geq 0.05$ and $\mathrm{VAF} \geq 0.3$ was assessed initially for treatment assignment. Patients were assigned in dominant clone fashion if clones harboring mutations with $\mathrm{VAF} \geq 0.3$ determined by HTS, FLT3-ITD allelic ratio of $\geq 0.05$ or particular cytogenetic abnormalities were identified. For patients not assigned to any genetic group during the initial stratification, a second runthrough of the algorithm was performed searching for a clone with mutations with $\mathrm{VAF} \geq 0.2$ excluding FLT3ITD. As this algorithm is designed to assign therapy and assess outcome on an intent-to-treat basis, patients who suffered ED were included.

\section{Statistical analyses}

We made comparisons among groups regarding baseline characteristics, co-occurring mutations, and outcomes using Fisher's exact test for categorical variables, the Kruskal-Wallis test for continuous variables, and the Kaplan-Meier method and log rank test for survival endpoints [38]. Data collection and statistical analyses were performed by the Alliance Statistics and Data Center using SAS 9.4 and TIBCO Spotfire S + 8.2 with a dataset locked on September 12, 2019, and median follow-up of 8.6 years. Clinical endpoints are defined in the Additional file 1. 
Table 1 CALGB Protocol Chemotherapy Regimens

\begin{tabular}{|c|c|c|c|}
\hline Protocol & Induction & & Maintenance \\
\hline $\begin{array}{l}8321 \\
(n=3)\end{array}$ & $\begin{array}{l}\text { Randomized to: } \\
\text { *DNR Days } 1-3 \text { ( } 45 \mathrm{mg} / \mathrm{m}^{2} / \text { day }<60 \text { years or } \\
\left.30 \mathrm{mg} / \mathrm{m}^{2} / \text { day } \geq 60 \text { years }\right) \\
\text { Ara-C Days } 1-7\left(100 \mathrm{mg} / \mathrm{m}^{2} / \text { day }\right) \\
\text { VERSUS } \\
\text { *DNR Days } 1-3\left(45 \mathrm{mg} / \mathrm{m}^{2} / \text { day }<60 \text { years or }\right. \\
\left.30 \mathrm{mg} / \mathrm{m}^{2} / \text { day } \geq 60 \text { years }\right) \\
\text { Ara-C Days } 1-7\left(200 \mathrm{mg} / \mathrm{m}^{2} / \text { day CIV }\right)\end{array}$ & $\begin{array}{l}\text { 6-TG Days } 1-10\left(100 \mathrm{mg} / \mathrm{m}^{2} \text { PO q12 }\right. \\
\text { hour } \times 10 \text { doses) } \\
\text { DNR Day } 57 \text { ( } 45 \mathrm{mg} / \mathrm{m}^{2} / \text { day }<60 \text { years or } \\
30 \mathrm{mg} / \mathrm{m}^{2} / \text { day } \geq 60 \text { years) } \\
\text { Ara-C Days } 1-10,29-38,57-66,84-92 \text { (per } \\
\text { Induction assignment BID q12 hours } \times 10 \\
\text { doses) } \\
\text { VCR Days } 29 \text { and } 84\left(2 \mathrm{mg} / \mathrm{m}^{2}(\max 2 \mathrm{mg})\right) \\
\text { Prednisone Days } 29-33,84-88\left(40 \mathrm{mg} / \mathrm{m}^{2} /\right. \\
\text { day } \times 5 \text { days) }\end{array}$ & $\mathrm{n} / \mathrm{a}$ \\
\hline $\begin{array}{l}8525 \\
(n=41)\end{array}$ & $\begin{array}{l}\text { *DNR Days } 1-3\left(45 \mathrm{mg} / \mathrm{m}^{2} / \text { day }<60 \text { years or }\right. \\
\left.30 \mathrm{mg} / \mathrm{m}^{2} / \text { day } \geq 60 \text { years }\right) \\
\text { Ara-C Days } 1-7\left(200 \mathrm{mg} / \mathrm{m}^{2} / \text { day CIV }\right)\end{array}$ & $\begin{array}{l}\text { Randomized to } 4 \text { Cycles: } \\
\text { Ara-C Days } 1-5\left(100 \mathrm{mg} / \mathrm{m}^{2} / \text { day CIV }\right) \\
\text { VERSUS } \\
\text { Days } 1-5\left(400 \mathrm{mg} / \mathrm{m}^{2} / \text { day CIV }\right) \\
\text { VERSUS } \\
\text { Days 1,3,5 }\left(3 \mathrm{gm} / \mathrm{m}^{2} \text { every } 12 \mathrm{~h} \text { for } 6 \text { total }\right. \\
\text { doses) }\end{array}$ & $\begin{array}{l}\text { 4 Cycles: } \\
\text { DNR Day } 1 \text { ( } 45 \text { mg/m²/day) } \\
\text { Ara-C Days } 1-5(100 \text { mg/m² q12 hours SQ) }\end{array}$ \\
\hline $\begin{array}{l}8721 \\
(n=1)\end{array}$ & $\begin{array}{l}\text { Ara-C Days } 1,2,8,9\left(3 \mathrm{gm} / \mathrm{m}^{2} \text { every } 12 \mathrm{~h}-8\right. \\
\text { doses total) } \\
\text { L-asparaginase Days 2, } 9\left(6000 \mathrm{IU} / \mathrm{m}^{2}\right) \\
\text { Allowed to repeat on Days } 15,16 \text { for both } \\
\text { agents if no response }\end{array}$ & $\begin{array}{l}2 \text { Cycles: } \\
\text { Ara-C Days 1,2,8,9 }\left(3 \mathrm{gm} / \mathrm{m}^{2} \text { every } 12 \mathrm{~h}-8\right. \\
\text { doses total) } \\
\text { L-asparaginase Days } 2,9\left(6000 \mathrm{IU} / \mathrm{m}^{2}\right)\end{array}$ & $\mathrm{n} / \mathrm{a}$ \\
\hline $\begin{array}{l}8821 \\
(n=1)\end{array}$ & $\begin{array}{l}\text { *DNR Days } 1-3(45 \text { mg/m²/day) } \\
\text { Ara-C Days } 1-7(200 \text { mg/m²/day CIV })\end{array}$ & $\begin{array}{l}\text { Randomized to Course } 1 \text { followed by } \\
\text { Course } \mathbf{2} \text { VERSUS Course } 2 \text { followed by } \\
\text { Course } 1 \text { : } \\
\text { Course } 1 \text { : ( } 1 \text { cycle) } \\
\text { Mitoxantrone Days } 1-3\left(12 \mathrm{mg} / \mathrm{m}^{2} / \text { day) }\right. \\
\text { Diaziquone Days } 1-5\left(28 \mathrm{mg} / \mathrm{m}^{2} / \text { day CIV) }\right. \\
\text { Course } 2 \text { : ( } 1 \text { cycle) } \\
\text { Etoposide Day } 1\left(2400 \mathrm{mg} / \mathrm{m}^{2} \mathrm{CIV}\right) \\
\text { Cytoxan Days } 3-6(50 \mathrm{mg} / \mathrm{kg} / \text { day })\end{array}$ & $\mathrm{n} / \mathrm{a}$ \\
\hline $\begin{array}{l}8923 \\
(n=38)\end{array}$ & $\begin{array}{l}\text { Randomized to: } \\
\text { *DNR Days } 1-3\left(45 \mathrm{mg} / \mathrm{m}^{2} / \text { day }\right) \\
\text { Ara-C Days } 1-7 \\
\left(200 \mathrm{mg} / \mathrm{m}^{2} / \text { day CIV) }\right. \\
\text { G-CSF Starting Day } 8 \\
\text { VERSUS } \\
\text { *DNR Days } 1-3\left(45 \mathrm{mg} / \mathrm{m}^{2} / \text { day) }\right. \\
\text { Ara-C Days } 1-7 \text { ( } 200 \mathrm{mg} / \mathrm{m}^{2} / \text { day CIV) } \\
\text { Placebo Starting Day } 8\end{array}$ & $\begin{array}{l}\text { Course 1: (up to } 4 \text { cycles) } \\
\left.\text { Ara-C Days } 1-5 \text { ( } 100 \mathrm{mg} / \mathrm{m}^{2} \mathrm{CIV}\right) \\
\text { Course 2: (up to } 2 \text { cycles) } \\
\text { Ara-C Days } 1-3\left(500 \mathrm{mg} / \mathrm{m}^{2} \mathrm{q} 12 \mathrm{~h} \times 6\right. \\
\text { doses) } \\
\text { Mitoxantrone Days } 1-3\left(5 \mathrm{mg} / \mathrm{m}^{2} \times 6 \text { doses) }\right.\end{array}$ & $\mathrm{n} / \mathrm{a}$ \\
\hline $\begin{array}{l}9420 \\
(n=18)\end{array}$ & $\begin{array}{l}\text { Randomized to: } \\
\text { *DNR Days 1-3 (dose-escalated to MTD } \\
40 \mathrm{mg} / \mathrm{m}^{2} / \text { day) } \\
\text { Etoposide Days } 1-3 \\
\text { (dose-escalated to MTD } 60 \mathrm{mg} / \mathrm{m}^{2} / \text { day) } \\
\text { Ara-C Days } 1-7 \text { (100 mg/m²/day CIV) } \\
\text { PSC-833 } 1.5 \mathrm{gm} / \mathrm{kg} \text { IV Days } 1-3 \text { for } 2 \mathrm{~h} \text {, fol- } \\
\text { lowed by } 10 \mathrm{mg} / \mathrm{kg} / \text { day CIV for } 72 \mathrm{~h} \\
\text { VERSUS } \\
\text { *DNR Days } 1-3 \text { (dose-escalated to MTD } \\
40 \mathrm{mg} / \mathrm{m}^{2} / \text { day) } \\
\text { Etoposide Days } 1-3 \\
\text { (dose-escalated to MTD } 60 \mathrm{mg} / \mathrm{m}^{2} / \text { day) } \\
\text { Ara-C Days } 1-7 \text { (100 mg/m²/day CIV) } \\
\text { No PSC-833 }\end{array}$ & $\begin{array}{l}\text { Randomized to } 1 \text { Cycle: } \\
\text { DNR Days } 1-2 \text { (30 mg/m²/day) } \\
\text { Etoposide Days } 1-2\left(60 \mathrm{mg} / \mathrm{m}^{2} / \text { day) }\right. \\
\text { Ara-C Days } 1-5 \text { (100 mg/m²/day CIV) } \\
\text { PSC-833 } 1.5 \mathrm{gm} / \mathrm{kg} \mathrm{IV} \mathrm{Days} 1-3 \text { for } 2 \mathrm{~h} \text {, fol- } \\
\text { lowed by } 10 \mathrm{mg} / \mathrm{kg} / \text { day CIV for } 72 \mathrm{~h} \\
\text { VERSUS } \\
\text { DNR Days } 1-2\left(30 \mathrm{mg} / \mathrm{m}^{2} / \text { day) }\right. \\
\text { Etoposide Days } 1-2\left(60 \mathrm{mg} / \mathrm{m}^{2} / \text { day }\right) \\
\text { Ara-C Days } 1-5\left(100 \mathrm{mg} / \mathrm{m}^{2} / \text { day CIV) }\right. \\
\text { No PSC-833 (based on initial induction } \\
\text { assignment) }\end{array}$ & $\begin{array}{l}\text { Randomized to: } \\
\text { R-IL2 }\left(0.9 \times 10^{6} \text { SQ Days } 1-14,19-28,33-42 \text {, }\right. \\
\quad 47-56,61-70,75-90 \text { and } 12 \times 10^{6} \text { Day } \\
\quad 15-17,29-31,43-45,57-59,71-73) \\
\text { VERSUS } \\
\text { No maintenance }\end{array}$ \\
\hline
\end{tabular}


Table 1 (continued)

\begin{tabular}{|c|c|c|c|}
\hline Protocol & Induction & & Maintenance \\
\hline $\begin{array}{l}9720 \\
(n=233)\end{array}$ & $\begin{array}{l}\text { Randomized to: } \\
\text { *DNR Days } 1-3\left(40 \mathrm{mg} / \mathrm{m}^{2} / \text { day }\right) \\
\text { Etoposide Days } 1-3\left(60 \mathrm{mg} / \mathrm{m}^{2} / \text { day) }\right. \\
\text { Ara-C Days } 1-7 \\
\left(100 \mathrm{mg} / \mathrm{m}^{2} / \text { day CIV) }\right. \\
\text { PSC-833 } 1.5 \mathrm{gm} / \mathrm{kg} \mathrm{IV} \mathrm{Days} 1-3 \text { for } 2 \mathrm{~h} \text {, fol- } \\
\text { lowed by } 10 \mathrm{mg} / \mathrm{kg} / \text { day CIV for } 72 \mathrm{~h} \\
\text { VERSUS } \\
\text { *DNR Days } 1-3\left(40 \mathrm{mg} / \mathrm{m}^{2} / \text { day }\right) \\
\text { Etoposide Days } 1-3\left(60 \mathrm{mg} / \mathrm{m}^{2} / \text { day }\right) \\
\text { Ara-C Days } 1-7\left(100 \mathrm{mg} / \mathrm{m}^{2} / \text { day CIV }\right) \\
\text { No PSC-833 }\end{array}$ & $\begin{array}{l}\text { Randomized to } 1 \text { Cycle: } \\
\text { DNR Days } 1-2\left(30 \mathrm{mg} / \mathrm{m}^{2} / \text { day) }\right. \\
\text { Etoposide Days } 1-2\left(60 \mathrm{mg} / \mathrm{m}^{2} / \text { day) }\right. \\
\text { Ara-C Days } 1-5\left(100 \mathrm{mg} / \mathrm{m}^{2} / \text { day CIV }\right) \\
\text { PSC-833 Days } 1-3(1.5 \mathrm{gm} / \mathrm{kg} \text { IV for } 2 \mathrm{~h} \text {, fol- } \\
\text { lowed by } 10 \mathrm{mg} / \mathrm{kg} / \text { day CIV for } 72 \mathrm{~h}) \\
\text { VERSUS } \\
\text { DNR Days } 1-2\left(30 \mathrm{mg} / \mathrm{m}^{2} / \text { day) }\right. \\
\text { Etoposide Days } 1-2\left(60 \mathrm{mg} / \mathrm{m}^{2} / \text { day) }\right. \\
\text { Ara-C Days } 1-5\left(100 \mathrm{mg} / \mathrm{m}^{2} / \text { day CIV) }\right. \\
\text { No PSC-833 (based on initial induction } \\
\text { assignment) }\end{array}$ & $\begin{array}{l}\text { Randomized to: } \\
\text { R-IL2 }\left(0.9 \times 10^{6} \text { SQ Days } 1-14,19-28,33-42 \text {, }\right. \\
\quad 47-56,61-70,75-90 \text { and } 12 \times 10^{6} \text { Day } \\
\quad 15-17,29-31,43-45,57-59,71-73) \\
\text { VERSUS } \\
\text { No maintenance }\end{array}$ \\
\hline $10201(n=168)$ & $\begin{array}{l}\text { Randomized to: } \\
\text { *DNR Days 4-6 (60 mg/m²/day) } \\
\text { Ara-C Days 4-10 (100 mg/m²/day CIV) } \\
\text { Oblimersen Days } 1-10 \text { (7 mg/kg/day CIV) } \\
\text { VERSUS } \\
\text { *DNR Days 4-6 (60 mg/m²/day) } \\
\text { Ara-C Days 4-10 (100 mg/m²/day CIV) } \\
\text { No Oblimersen }\end{array}$ & $\begin{array}{l}\text { Randomized to } 2 \text { Cycles: } \\
\text { Ara-C Days 4-8 (2000 mg/m²/daily) } \\
\text { Oblimersen Days } 1-8 \text { (7 mg/kg/day CIV) } \\
\text { VERSUS } \\
\text { Ara-C Days 4-8 ( } 2000 \mathrm{mg} / \mathrm{m}^{2} / \text { daily) } \\
\text { No Oblimersen }\end{array}$ & $\mathrm{n} / \mathrm{a}$ \\
\hline $\begin{array}{l}10502 \\
(n=35)\end{array}$ & $\begin{array}{l}\text { *DNR Days } 1-3\left(60 \mathrm{mg} / \mathrm{m}^{2} / \text { day }\right) \\
\text { Ara-C Days } 1-7\left(100 \mathrm{mg} / \mathrm{m}^{2} / \text { day CIV }\right) \\
\text { Bortezomib } 1.3 \mathrm{mg} / \mathrm{m}^{2} \text { Days } 1,4,8,11\end{array}$ & $\begin{array}{l}2 \text { Cycles: } \\
\text { Ara-C Days } 1-5\left(2 \mathrm{gm} / \mathrm{m}^{2} / \text { day }\right) \\
\text { Bortezomib per dose escalation Days } 1,4,8,11\end{array}$ & $\mathrm{n} / \mathrm{a}$ \\
\hline $\begin{array}{l}10801 \\
(n=13)\end{array}$ & $\begin{array}{l}{ }^{*} \text { DNR Days } 1-3(60 \text { mg/m²/day) } \\
\text { Ara-C Days } 1-7(200 \text { mg/m²/day CIV) } \\
\text { Dasatinib Days } 8-21 \text { (100 mg PO Daily) }\end{array}$ & $\begin{array}{l}4 \text { cycles: } \\
\text { Ara-C Days } 1,3,5\left(3 \mathrm{gm} / \mathrm{m}^{2} \mathrm{q} 12\right. \\
\text { hours }<60 \text { years and } 1 \mathrm{gm} / \mathrm{m}^{2} \mathrm{q} 12 \\
\text { hours } \geq 60 \text { years) } \\
\text { Dasatinib Days } 1-26 \text { ( } 100 \mathrm{mg} \text { PO daily) }\end{array}$ & Dasatinib 100 mg PO daily up to 12 months \\
\hline $\begin{array}{l}11001 \\
(n=11)\end{array}$ & $\begin{array}{l}\text { *DNR Days 1-3 (60 mg/m²/day) } \\
\text { Ara-C Days 1-7 (100 mg/m²/day CIV) } \\
\text { Sorafenib Days } 1-7(400 \text { mg daily) }\end{array}$ & $\begin{array}{l}2 \text { Cycles: } \\
\text { Ara-C Days 1-5 (2 gm/m²/day) } \\
\text { Sorafenib Days 1-28 (400 mg PO BID) }\end{array}$ & $\begin{array}{l}\text { Sorafenib } 400 \text { mg PO BID Days } 1-28 \text { up to } 12 \\
\text { cycles }\end{array}$ \\
\hline
\end{tabular}

Ara-C, cytarabine; BID, twice daily; CIV, continuous intravenous infusion; DNR, daunorubicin; gm, gram; h, hour; IU, international units; kg, kilogram; m, meter; mg, milligram; MTD, maximum tolerated dose; n, number; n/a, not applicable; PO, orally; q12, every 12; SQ, subcutaneous; VCR, vincristine; 6-TG, 6-Thioguanine

${ }^{*}$ Reinduction therapy allowed

\section{Results}

\section{Patient genetic group assignment}

We sought to establish the outcomes of patients treated on CALGB trials who were retrospectively assigned to specific genetic groups to serve as a historical control for comparison with future results of the Beat AML trial. Using the algorithm, 498 (88\%) patients were assigned to a genetic group based upon cytogenetic findings or the presence of a dominant mutational clone with $\mathrm{VAF} \geq 0.3$. This number increased to 508 (90\%) when an additional $10(2 \%)$ patients were reassigned following detection of a clone with a mutation with $\mathrm{VAF} \geq 0.2$. There were $75(13 \%)$ patients assigned to the CBF group, 107 (19\%) to the NPM1m/FLT3ITD- group, 13 (2\%) to the KMT2A group, 59 (10\%) to the $I D H 2 \mathrm{~m}$ group, $35(6 \%)$ to the $I D H 1 \mathrm{~m}$ group, 50 (9\%) to the TP53m group, $28(5 \%)$ to the complex karyotype/TP53wt group, $99(18 \%)$ to the FLT3m group, and $42(7 \%)$ to the TET2m or WT1m group. The remaining $56(10 \%)$ patients were assigned to the marker-negative group (Table 2).

\section{Clinical, cytogenetic and molecular genetic characteristics} of patients classified into genetic groups

Baseline clinical characteristics among groups were similar with the following exceptions: (1) CBF and NPM1m/FLT3-ITD - patients had almost an equal maleto-female ratios whereas other groups had predominance of male patients; (2) platelet counts were highest in the $I D H 1 \mathrm{~m}$ group; (3) the white blood cell counts were highest in the FLT3m, KMT2A and NPM1m/FLT3-ITDgroups; and (4) percentage of BM blasts were highest in the KMT2A, IDH1m, and the FLT3m groups (Table 3).

We next analyzed occurrence of mutations belonging to the previously reported functional groups [39] within each of the genetic groups identified in the current study (Additional file 1: Table S1). We found that NPM1m/FLT3-ITD-patients had most often gene mutations in the methylation-related (87\%), RAS pathway (47\%), and spliceosome (28\%) functional groups. In the KMT2A group, gene mutations were infrequent as previously reported [40] and the mutations occurring most frequently were those in genes belonging to 
Fig. 1 Genetic group assignment algorithm. Patients were assigned to a genetic group with initial run-through of the algorithm based on cytogenetic features or molecular mutational clones with VAF $\geq 0.3$. For patients not assigned to any genetic group during the initial stratification, a second run-through of the algorithm was performed with assignment after assessing for a mutational clone with $\mathrm{VAF} \geq 0.2$. $C B F$, Core-Binding Factor; Complex, Complex karyotype

the methylation-related (23\%) functional group. Both $I D H 2 \mathrm{~m}$ and $I D H 1 \mathrm{~m}$ frequently had mutations in genes from spliceosome (57 and 34\%, respectively), chromatin remodeling (29 and 31\%), kinases (25 and 46\%), and transcription factors (29 and $21 \%$ ) functional groups. The most common co-mutations in TP53m patients were in genes from the methylation-related functional group (24\%). In the complex karyotype/TP53wt genetic group, most often mutated were genes from spliceosome (36\%) and methylation-related (32\%) functional groups. The FLT3m genetic group had high frequency of methylationrelated (59\%), NPM1 (55\%), transcription factors (29\%) and spliceosome (26\%) mutations. Patients in the TET2m or $W T 1 \mathrm{~m}$ and the marker-negative groups had high frequency of mutations in genes belonging to spliceosome (61 and 45\%), transcription factors (36 and 64\%), chromatin remodeling (50 and 46\%), and RAS pathway (24 and 36\%) functional groups (Additional file 1: Table S1).

Frequencies of individual gene mutations in patients assigned to the genetic groups are provided in Additional file 1: Table S2. For better visualization of the mutational spectrum of each of the genetic patient groups, we created an oncoprint depicting gene mutations found in each genetic group (Fig. 2). Of note, the NPM1m/FLT3ITD- genetic group had concurrently occurring mutations in the TET2 (33\%), IDH2 (21\%), and IDH1 (21\%), TP53 (1\%) genes, and FLT3-TKD (13\%). Patients in the $I D H 2 \mathrm{~m}$ group did not harbor a concurrent IDH1 mutation nor did patients in the $I D H 1 \mathrm{~m}$ group harbor simultaneously an $I D H 2$ mutation. The complex karyotype/ TP53wt genetic group did include a low frequency of TP53 mutations $(n=2)$, and in both patients the VAF of these mutations was $<0.2$. The FLT3m genetic group had high frequency of NPM1 (55\%), DNMT3A (40\%) and TET2 (25\%) mutations. The marker-negative genetic group included a relatively high frequency of RUNX1 (43\%), ASXL1 (25\%), NRAS (21\%), and U2AF1 (20\%) mutations.

\section{Treatment outcome based on patient genetic groups}

ED occurred in $20 \%$ of all patients, most commonly in the TP53m (42\%), KMT2A (23\%), IDH1m (23\%), and FLT3m (23\%) groups. All other groups had ED rates between 17 and $20 \%$, except for the CBF group, which had no ED

\section{$>$}

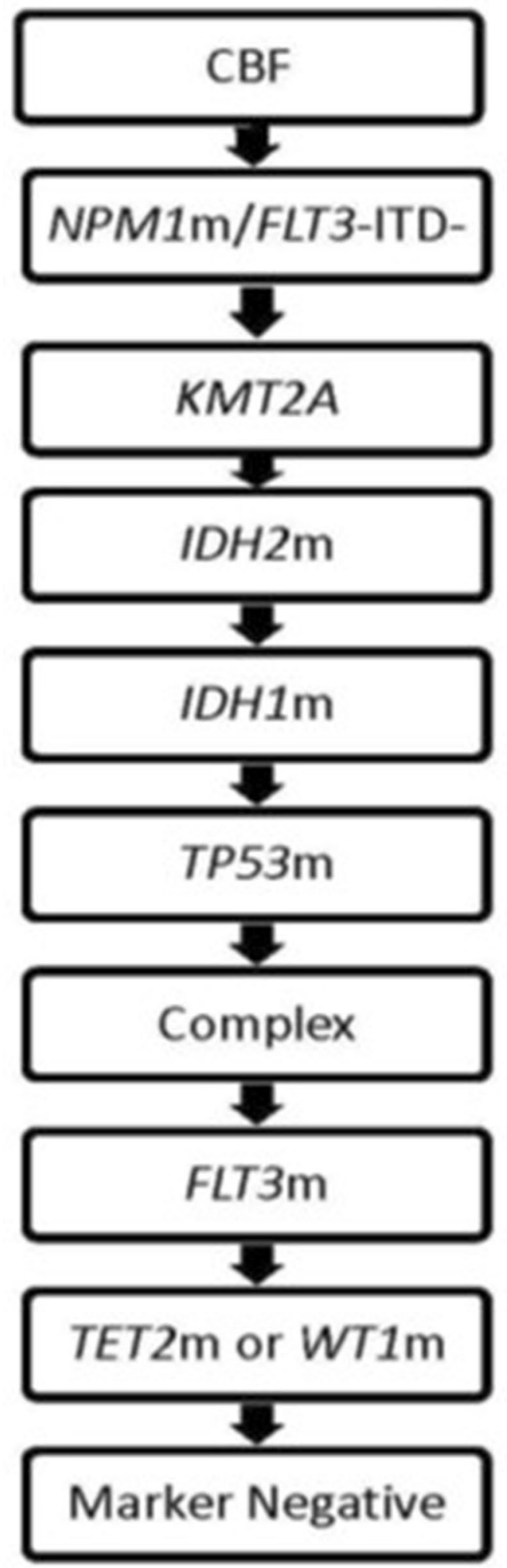


Table 2 Retrospective assignment of 589 patients receiving standard therapy on CALGB/Alliance trials to Beat AML genetic treatment groups

\begin{tabular}{|c|c|c|c|c|}
\hline \multirow[t]{4}{*}{ Assignment } & \multicolumn{3}{|c|}{ Performed concurrently } & \multirow[t]{3}{*}{ Final assignment } \\
\hline & Step 1 & Step 2 & Step 3 & \\
\hline & Initial assignment & Initial assignment & Reassignment & \\
\hline & Cytogenetics & $\operatorname{VAF} \geq 0.3$ & $\mathrm{VAF} \geq 0.2$ & $\begin{array}{l}\text { Total number of } \\
\text { patients } \\
n(\%)\end{array}$ \\
\hline Core-binding factor & 74 & - & - & $74(13)$ \\
\hline NPM1m/FLT3-ITD- & - & 106 & 1 & 107 (19) \\
\hline KMT2A & 13 & - & - & $13(2)$ \\
\hline $\mathrm{IDH} 2 \mathrm{~m}$ & - & 56 & 3 & $59(10)$ \\
\hline $\mathrm{IDH} 1 \mathrm{~m}$ & - & 33 & 2 & $35(6)$ \\
\hline TP53m & - & 50 & - & $50(9)$ \\
\hline Complex karyotype/TP53wt & 28 & - & - & $28(5)$ \\
\hline FLT3m & - & 96 & 3 & $99(18)$ \\
\hline TET $2 \mathrm{~m}$ or $W T 1 \mathrm{~m}$ & - & 41 & 1 & $42(7)$ \\
\hline Marker-negative & - & 66 & -10 & $56(10)$ \\
\hline $\begin{array}{l}\text { Total number of assigned patients } \\
\text { per column }\end{array}$ & 115 & 448 & 10 & 563 \\
\hline
\end{tabular}

$m$, mutated; $n$, number; VAF, variant allele frequency; wt, wild-type

(Table 4). The CR rates were above $50 \%$ in the two favorable risk groups: CBF (73\%), and NPM1m/FLT3-ITD$(68 \%)$ and $62 \%$ in the intermediate risk group KMT2A. However, in the other groups the CR rates ranged between 32 and 47\%, except for TP53m group, in which CR rate was much lower at $16 \%$. These CR rates were not affected by selection bias for patients surviving early AML treatment complications or progression and thus provide a historical control for new therapies in specific molecular/cytogenetic groups defined herein.

Concerning long-term outcomes, the median DFS was less than a year for all patients except for those in the NPM1m/FLT3-ITD- group, for whom median DFS was exactly 1 year. The 3 -year DFS rates were less than $15 \%$ for all genetic groups but the two favorable groups of CBF (30\%) and NPM1m/FLT3-ITD- (27\%) that included some patients with long-term benefit from standard treatment (Table 4 and Fig. 3). Median OS was less than 1 year in all groups other than the two favorable risk ones: CBF with median OS of 1.5 years and NPM $1 \mathrm{~m} / F L T 3-$ ITD- with median OS of 1.3 years. The 3 -year OS rates were less than $10 \%$ in all groups except for CBF (33\%), NPM1m/FLT3-ITD- (27\%), and IDH2m (15\%).

\section{Discussion}

Our analysis demonstrates the outcomes of classifying older AML patients based on a precision-based medicine assignment of the LLS Beat AML Master Study using both targetable cytogenetic abnormalities and gene mutations found in dominant mutational clones, defined as those having $\mathrm{VAF} \geq 0.3$, or $\mathrm{VAF} \geq 0.2$ (in cases with no selected mutations with $\mathrm{VAF} \geq 0.3$ ), or FLT3-ITD allelic ratio of $\geq 0.05$. The majority of patients $(90 \%)$ were assigned to a genetic group as a result of the run-through of the algorithm based initially on either cytogenetic findings, FLT3-ITD allelic ratio of $\geq 0.05$ or detection of gene mutations with a VAF $\geq 0.3$, followed by a second run-through of $\mathrm{VAF} \geq 0.2$. Only $10 \%$ of patients were assigned to the marker-negative group that included patients with mutations in the spliceosome (mostly SRSF2 and U2AF1), RUNX1, ASXL1, and NRAS genes (though the other treatment assignment genomic groups could include these mutations as well). These mutations are currently not targetable with any available therapeutic. However, as we have gained more knowledge since the original design of this algorithm, including potential mutations that lead to resistance in certain targeted therapeutics and new available therapeutics as aforementioned, other mutational genomic subgroups such as $R A S$ mutated patients are being added to the algorithm and the reordering of the algorithm genomic subgroups (such as FLT3 mutations being higher up in the stratification) are occurring. Despite this, application of this dataset did not reveal any concerns in regard to our algorithm with inappropriate genetic assignments that would preclude patients from receiving curative therapy. The outcomes of this approach prompted inclusion of this assignment 


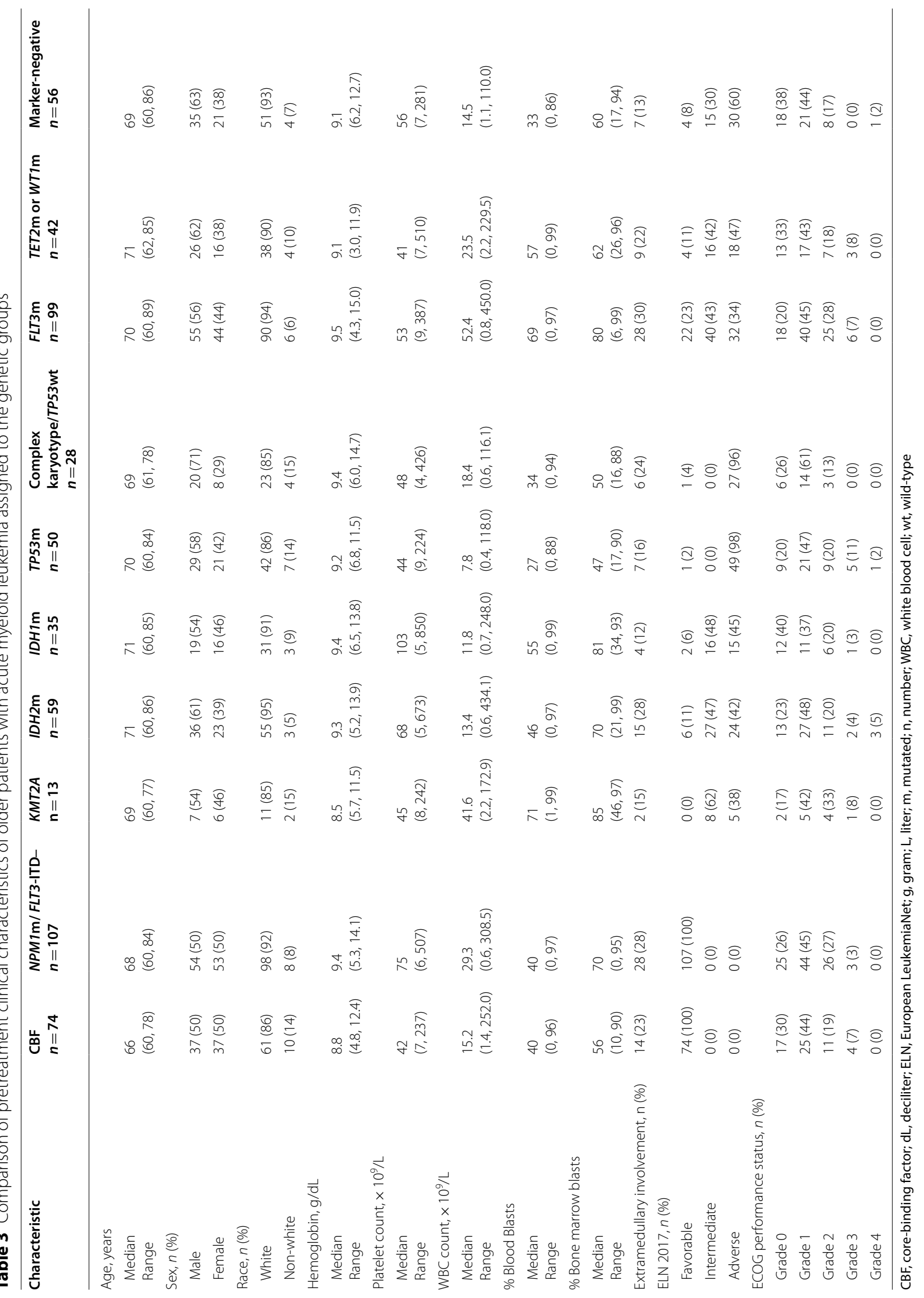



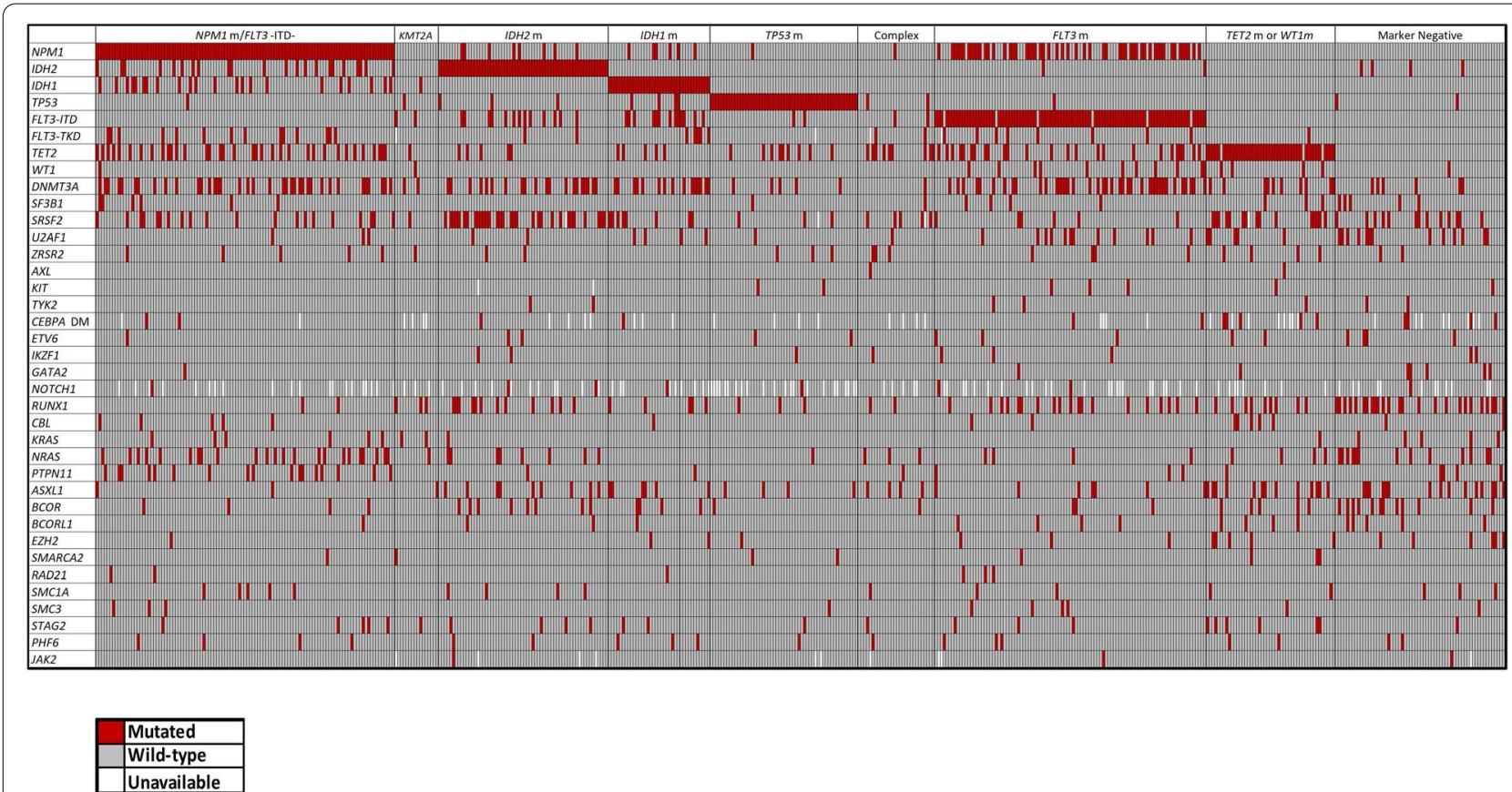

Fig. 2 Oncoprint of co-occurring mutations found in older acute myeloid leukemia patients assigned to genetic groups. The top row colors depict each genetic group as outlined in the figure. Each column represents an individual patient and each row under the top row represents a single gene mutation. For the single gene mutation rows, the red color indicates that a gene was found to be mutated in the patient, gray indicates wild-type status of the gene, and white indicates unavailable gene mutation status. DM, double mutated

algorithm in the Beat AML trial (https://www.lls.org/ beat-aml).

With regard to outcomes of our patients treated with standard therapies who were assigned to genetic groups, the findings were similar to what has been reported in older AML patients. Patients in the more favorable genetic groups of CBF and NPM1m/FLT3-ITD- fared best, but overall the patients had poor long-term outcomes with standard treatment approaches [41, 42]. Although we are making progress with the addition of such agents as midostaurin [9], venetoclax [4], glasdegib $[13,43]$, and other newly approved targeted therapies to achieve short-term goals of improved CR rates, DFS and $\mathrm{OS}$, these therapies remain non-curative and need to be built and improved upon further.

It is also of importance, with new treatment approaches becoming available, to understand how best to decide among multiple potential therapeutic options, both from a clinician and patient perspective. Data presented herein have served as the historical control for individual Beat AML genomic substudies statistical design at the initiation of this study and have served as benchmarks for clinical outcome improvement for particular AML genomic patient groups. This has allowed determination of clinical progress made in older AML patients and in specific genetic groups to advance novel therapies and aid in better selection of treatment. The inclusion of ED patients, who have typically been excluded from other prognostic studies, is important because this helps in assessing true outcomes of patients assigned to specific genetic groups. This information is also of value in determining if newer therapeutic options are superior to standard treatment and associated toxicities. Rates of ED observed in specific genetic groups could aid in making treatment decisions for patients that potentially influence quality of life, especially when deciding between therapies with non-curative intent. In this regard, it is notable that a very high-risk TP53m group had a 30-day ED rate of $41 \%$ that corresponds to the low induction success rate of $17 \%$. These data clearly identify a distinct genetic group for which standard of care induction with $7+3$ chemotherapy lacks therapeutic benefit. Notably, all other groups outside of CBF AML had an ED rate of $17 \%$ or more indicating that in the historical setting, $7+3$ chemotherapy treatment and potential increased risk of infections and other complications arising from other comorbid illnesses brings early risk to elderly patients. Adaptation of functional assessment models [44, 45] or other pretreatment models $[46,47]$ to identify patients at risk for ED in choosing chemotherapy approaches is needed. Clinical trials in elderly AML have focused predominantly on OS as the primary endpoint for analysis, 


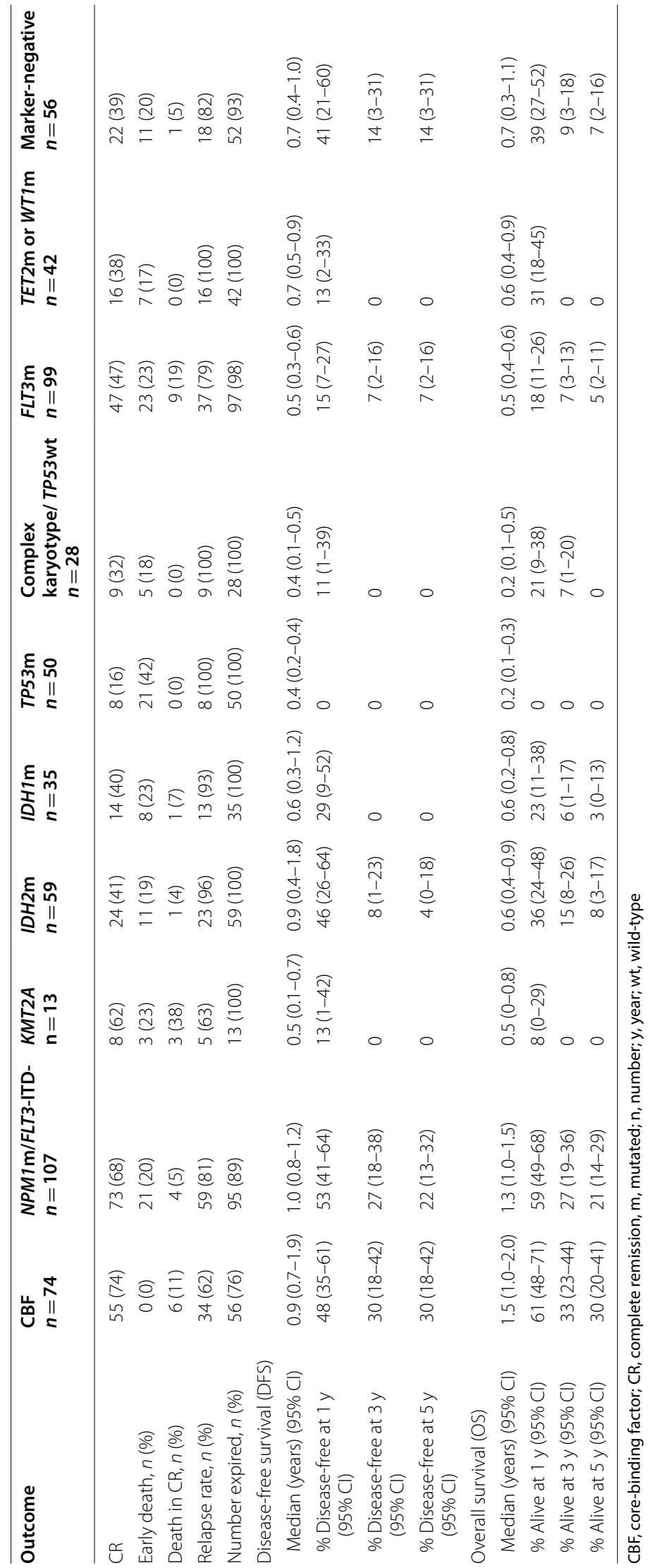




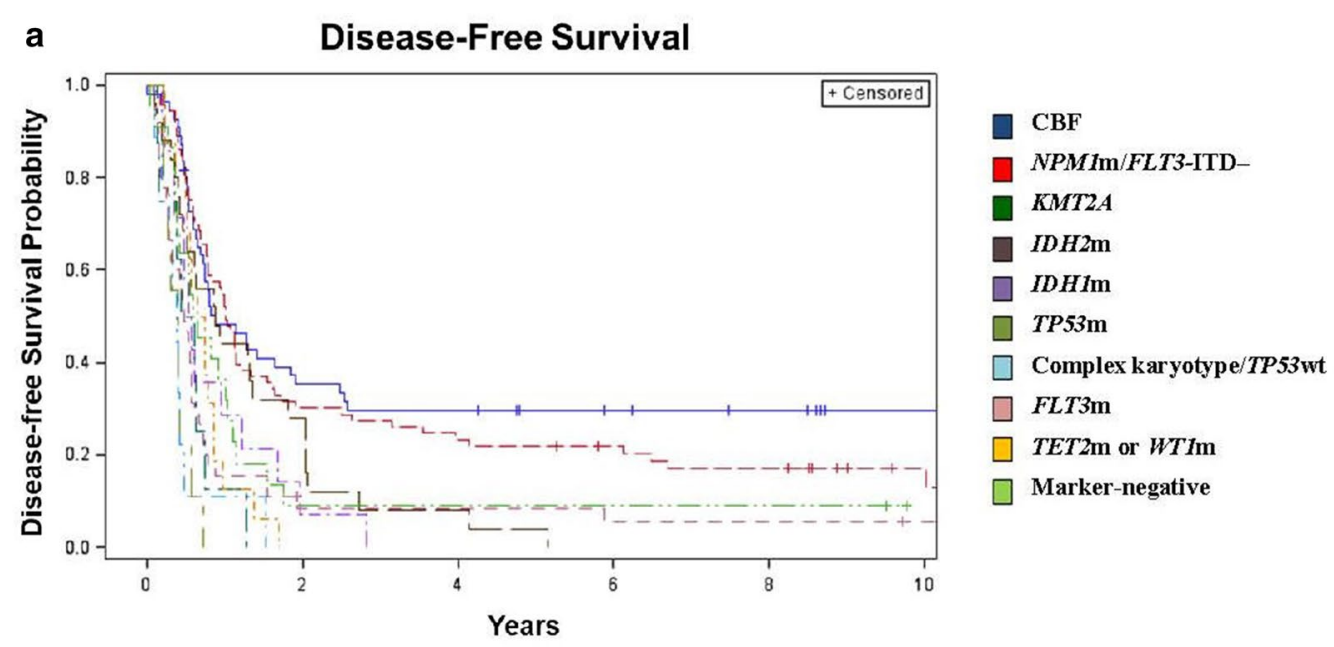

b Overall Survival

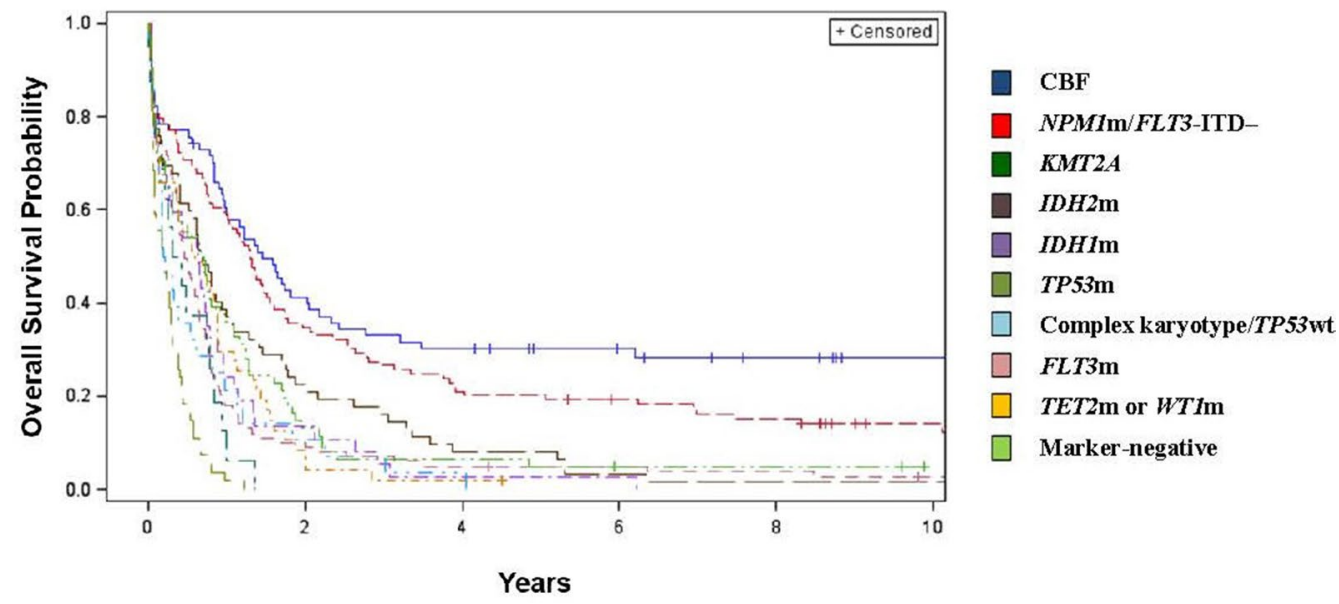

Fig. 3 Kaplan-Meier curves depicting the $\mathbf{a}$ disease-free survival and $\mathbf{b}$ overall survival of older patients with acute myeloid leukemia classified into genetic groups. Each genetic group is identified by color as outlined in the figure

particularly when considering regulatory actions [11, 48]. Although this endpoint is of utmost importance, the potential impact of ED on the patient's family well-being may serve to justify ED rate as another surrogate outcome for new therapies with less morbidity than chemotherapy in this disease. Examination of all aspects of ED is a major focus of the precision medicine LLS Beat AML Master Study.

The oncoprint depiction of the genetic groups defined in our prioritization is based on observations made by others [3, 49, 50]. Specifically, the KMT2A and TP53m genetic groups have very little overlap with other common AML mutations as reported by others, suggesting that both $11 \mathrm{q} 23 / K M T 2 A$ rearrangements [40] and TP53 mutations [3] are strong drivers of the disease. Notably, no $(K M T 2 A)$ or little $(T P 53 \mathrm{~m})$ overlap occurred with prognostically favorable mutations such as NPM1 mutations or with mutations in the IDH2 and IDH1 genes, for which there are definitive targeted therapies with proven benefit [6-8]. As more directed FLT3 inhibitors are now available, the FLT3m group is moving higher up in the treatment algorithm. Also discerned from this oncoprint, one can observe that NRAS, KRAS and/or PTPN11 mutations overlap with the $I D H 1 \mathrm{~m}, I D H 2 \mathrm{~m}$, and $F L T 3 \mathrm{~m}$ groups but are relatively infrequent. As targeted therapies directed at $I D H 2, I D H 1$, and FLT3 are available, it is notable that NRAS or PTPN11 mutations can represent pretreatment or acquired alterations that lead to primary or secondary resistance $[51,52]$. As more data comes forth from studies with targeted therapy, it has been necessary 
to re-examine prioritization of patients with $N R A S$ and PTPN11 mutations and potentially those with other mutations, such as $C B L$ or $N F 1$, which activate RAS/ MAPK signaling, to include these patients as a separate genomic subgroup. Finally, examination of the markernegative group demonstrates enrichment of patients with RUNX1, ASXL1, and spliceosome mutations that might be amendable to specific targeted therapies in the future. Future decisions to change the algorithm for the Beat AML study will also be based upon the ability to identify relevant and best directed therapeutic options.

Limitations of this study include its retrospective nature, changes in practice patterns for AML therapy over time, and lack of measurable residual disease data (MRD) to correlate with outcomes. However, despite being treated on different Alliance protocols, outcomes in regard to CR, DFS, and OS are similar between all treatment arms of the various protocols (Fig. 4). Patients received intensive regimens with different doses of anthracycline for induction and varied consolidation therapies. There was also inclusions of patients on CALGB 9720 and 9420 which were closed early due to early mortality on the investigational arms but only 32 patients in our analysis were included in treatment arms with PSC-833 with 11 of these patients being included for early death. Another major limitation is the broad range of time for the study enrollment for patients analyzed in this dataset. Supportive care for AML has improved over time with inclusion of better anti-emetics, proton pump inhibitor drugs, antifungal prophylaxis, and treatment of infectious complications and other complications, which has led to improvement in outcomes for patients and may have improvement on ED rates than what is included in our dataset. However, data from the Swedish AML Registry which began collecting patient in 2005 included newly diagnosed AML patient 60-74 with AML with NPM1m/FLT3ITDtreated with intensive chemotherapy had only slightly improved survival data compared to our findings. These patients had a median OS of 1.49 years compared to our findings of 1.33 years and 3 year OS of $35.5 \%$ in comparison to our finding of $27 \%$ [53]. Patients included in this analysis were also enrolled onto clinical trials at multiple centers, which may not be reflective of treatment given outside of clinical trials. Also our patients were not transplanted in first CR, which likely contributes to poor long-term outcomes; however, this is likely more akin to real-world data as the majority of older AML patients are, unfortunately, still not being considered for transplantation and many still remain untreated [54-56]. Albeit, this may hopefully improve with additional new less intensive treatment options that be more feasible to give in the community setting.

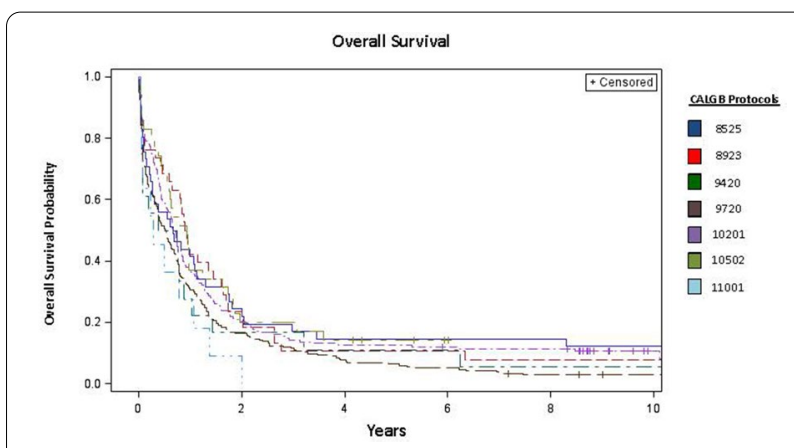

Fig. 4 Kaplan-Meier curves depicting the overall survival of older patients with acute myeloid leukemia as treated per individual CALGB regimen. Each study is identified by color as outlined in the figure

Also, our analysis included only patients whose AML had both cytogenetic and mutational studies performed from diagnostic samples, a potential selection bias. Finally, our analysis lacks any MRD assessments and correlation to patient clinical outcomes although efforts to add this to Alliance/CALGB patient dataset analyses are currently underway. The use of MRD assessments in AML is evolving in regard to methodology and standardization, as well as timing and threshold of meaningful MRD positivity [57]. Although assessment of AML MRD remains complicated, current efforts are underway to implement multimodality MRD testing in clinical trials including the Beat AML study. It is hopeful that MRD testing can become standardized and a routine part of AML patient clinical care in order to continue to improve treatment outcomes. Despite these limitations to our dataset, our study represents one of the largest series of older AML patients with inclusion of all newly diagnosed patients regardless of early death in order to most accurately define outcomes of specific genetic groups relevant to the ongoing Beat AML study.

\section{Conclusions}

As more treatments in AML are explored in the upfront setting, this historical outcome data from patients treated with standard treatment on CALGB/Alliance protocols can aid in determining appropriate milestone achievements for potential trial design. This dataset has been used for Beat AML genomic Phase 1/2 substudy statistical designs to determine primary endpoints. If dramatic improvements with new therapeutics are seen from these baseline expectations, the goal is to lead to rapid drug approval in this older AML population. However, as outcome data matures for newer approved treatment modalities in older AML patients, new benchmarks will be set for therapeutic clinical trials to further improve upon the 
recent progress that has been made in this patient population. This is particularly relevant for small genetic groups where randomized trials may not be possible. To extend the results reported herein, we will be validating our findings through analysis of a multi-institutional cohort and, ideally, in a series that includes other standards of care for elderly AML currently used in practice such as HMA [58] or venetoclax combined with HMA [4]. We also plan to assess the potential impact of co-mutations on treatment outcomes and compare data from our retrospective patient cohort in the prospective Beat AML patient data. Our hope is that genetics-based approaches will result in continued improved outcomes in both older and younger AML patient populations and lead to curative therapies, not just short-term improvements.

\section{Abbreviations}

AML: Acute myeloid leukemia; BM: Bone marrow; CALGB: Cancer and leukemia group B; CBF: Core-binding factor; CR: Complete remission; DFS: Disease-free survival; ED: Early death; FLT3m: FLT3-ITD (both high and low allelic ratios included) or FLT3-TKD; HMA: Hypomethylating agents; HTS: High throughput sequencing; IDHI m: IDH1 Mutated; IDH2 m: IDH2 Mutated; KMT2A 11Q23/KMT2A-rearranged; LLS: Leukemia and Lymphoma Society; OS: Overall survival; PCR: Polymerase chain reaction; TET2m: TET2 Mutated; TP53m: TP53 Mutated; TP53wt: TP53 Wild-type; VAF: Variant allele frequency; WT1m: WT1 Mutated.

\section{Supplementary Information}

The online version contains supplementary material available at https://doi. org/10.1186/s13045-021-01110-5.

Additional file 1. Supplementary Material.

\section{Acknowledgements}

The authors are grateful to the patients who consented to participate in these clinical trials and the families who supported them; to Donna Bucci, Christopher Manring and the CALGB/Alliance Leukemia Tissue Bank at The Ohio State University Comprehensive Cancer Center, Columbus, OH, for sample processing and storage services and Lisa J. Sterling for data management.

\section{Authors' contributions}

$A S M, J K, A B, R L L, U B, E S, B J D$, and JCB contributed to the study design; ASM, $J K, K M$, and JCB contributed to the data interpretation, ASM, JK, KM, and JCB wrote the manuscript; ASM, A-KE, JSB, and SO performed laboratory-based research; JSB performed the data processing; JK performed statistical analysis; $U B, E S, R M S$, JEK, ESW, CDB, and JCB were involved directly or indirectly in the care of patients and/or sample procurement. All authors read and agreed on the final version of the manuscript. The authors dedicate this paper to $\mathrm{CDB}$, who died unexpectedly as this manuscript was being completed. Her mentorship and support fostered all of us to pursue novel approaches to improve outcome for AML patients. All authors read and approved the final manuscript.

\section{Funding}

Research reported in this publication was supported by the National Cancer Institute of the National Institutes of Health under Award Numbers U10CA180821, U10CA180882 and U24CA196171 (to the Alliance for Clinical Trials in Oncology), UG1CA233338, UG1CA233331, P50CA140158, U10CA180861, P30CA016058, P30CA008748, R35 CA198183, U10CA180888 (SWOG), the Leukemia Clinical Research Foundation, the D. Warren Brown Foundation, The Harry Mangurian Foundation, the Alliance Clinical Scholar program (to AS Mims), the American Society of Hematology Clinical Scholar program (to AS Mims), and by an allocation of computing resources from The Ohio Supercomputer Center. The content is solely the responsibility of the authors and does not necessarily represent the official views of the National Institutes of Health. https://acknowledgments.alliancefound.org.

\section{Availability of data and materials}

For original data, please contact Alice.Mims@osumc.edu.

\section{Declarations}

\section{Ethics approval and consent to participate}

Patients provided written informed consent to participate in companion protocols CALGB 8461 (cytogenetic studies), CALGB 9665 (leukemia tissue bank), and CALGB 20202 (molecular studies), which involved collection of pretreatment BM and blood samples. Treatment protocols were in accordance with the Declaration of Helsinki and approved by the institutional review boards at each center participating in the CALGB/Alliance treatment protocols, and all patients provided written informed consent.

\section{Consent for publication}

Not applicable.

\section{Competing interests}

The authors declare no conflicts of or competing interest.

\section{Author details}

${ }^{1}$ The Ohio State University Comprehensive Cancer Center, 320 West 10th Avenue, Starling Loving Hall B302, Columbus, OH 43210, USA. ${ }^{2}$ Alliance Statistics and Data Center, The Ohio State University Comprehensive Cancer Center, Columbus, OH, USA. ${ }^{3}$ The Ohio State University Comprehensive Cancer Center, Clara D. Bloomfield Center for Leukemia Outcomes Research, Columbus, OH, USA. ${ }^{4}$ Memorial Sloan Kettering Cancer Center, New York, NY, USA. ${ }^{5}$ Dana-Farber/Partners CancerCare, Boston, MA, USA. ${ }^{6}$ Monter Cancer Center, Hofstra Northwell School of Medicine, Lake Success, NY, USA. ${ }^{7}$ Roswell Park Comprehensive Cancer Center, Buffalo, NY, USA. ${ }^{8}$ Wake Forest Baptist Comprehensive Cancer Center, Winston-Salem, NC, USA. ${ }^{9}$ The Leukemia and Lymphoma Society, White Plains, NY, USA. ${ }^{10}$ Oregon Health and Science University, Portland, OR, USA. ${ }^{11}$ The Ohio State University Comprehensive Cancer Center, 455 CCC Wiseman Hall, 400 West 12th Avenue, Columbus, $\mathrm{OH}$ 43210-1228, USA.

Received: 5 April 2021 Accepted: 4 June 2021

Published online: 23 June 2021

\section{References}

1. Arber DA, Orazi A, Hasserjian R, et al. The 2016 revision to the World Health Organization classification of myeloid neoplasms and acute leukemia. Blood. 2016;127(20):2391-405.

2. Döhner H, Estey E, Grimwade D, et al. Diagnosis and management of AML in adults: 2017 ELN recommendations from an international expert panel. Blood. 2017;129(4):424-47.

3. Papaemmanuil E, Gerstung G, Bullinger L, et al. Genomic classification and prognosis in acute myeloid leukemia. N Engl J Med. 2016;374(23):2209-21.

4. DiNardo CD, Pratz K, Jonas BA, Pullarkat $\mathrm{V}$, et al. Azacitidine and venetoclax in previously untreated acute myeloid leukemia. $\mathrm{N}$ Engl $\mathrm{J}$ Med. 2020;383(7):617-29.

5. Wei AH, Strickland SA, Hou JZ, et al. Venetoclax combined with low-dose cytarabine for previously untreated patients with acute myeloid leukemia: results from a phase Ib/II study. J Clin Oncol. 2019;37(15):1277-84.

6. Stein EM, DiNardo CD, Pollyea DA, et al. Enasidenib in mutant IDH2 relapsed or refractory acute myeloid leukemia. Blood. 2017;130(6):722-31.

7. DiNardo CD, Stein EM, de Botton S, et al. Durable remissions with ivosidenib in IDH1-mutated relapsed or refractory AML. N Engl J Med. 2018;378(25):2386-98.

8. Roboz GJ, DiNardo CD, Stein EM, et al. Ivosidenib induces deep durable remissions in patients with newly diagnosed IDH1-mutant acute myeloid leukemia. Blood. 2020;135(7):463-71. 
9. Stone RM, Mandrekar SJ, Sanford BL, et al. Midostaurin plus chemotherapy for acute myeloid leukemia with a FLT3 mutation. N Engl I Med. 2017;377(5):454-64.

10. Perl AE, Martinelli G, Cortes JE, et al. Gilteritinib or chemotherapy for relapsed or refractory FLT3-mutated AML. N Engl J Med. 2019;381(18):1728-40.

11. Lancet JE, Uy GL, Cortes JE, et al. CPX-351 (cytarabine and daunorubicin) liposome for injection versus conventional cytarabine plus daunorubicin in older patients with newly diagnosed secondary acute myeloid leukemia. J Clin Oncol. 2018;36(26):2684-92.

12. Hills RK, Castaigne S, Appelbaum FR, et al. Addition of gemtuzumab ozogamicin to induction chemotherapy in adult patients with acute myeloid leukemia a meta-analysis of individual patient data from randomized controlled trials. Lancet Oncol. 2014;15(9):986-96.

13. Cortes JE, Heidel FH, Hellman A, et al. Randomized comparison of low dose cytarabine with or without glasdegib in patients with newly diagnosed acute myeloid leukemia or high-risk myelodysplastic syndrome. Leukemia. 2019:33(2):379-89.

14. Appelbaum FR, Gundacker $\mathrm{H}$, Head DR, et al. Age and acute myeloid leukemia. Blood. 2006:107(9):3841-5.

15. Marcucci G, Mrózek K, Ruppert AS, et al. Prognostic factors and outcome of core binding factor acute myeloid leukemia patients with $\mathrm{t}(8 ; 21)$ differ from those of patients with inv(16): a Cancer and Leukemia Group B study. J Clin Oncol. 2005;23(24):5705-17.

16. Appelbaum FR, Kopecky KJ, Tallman MS, et al. The clinical spectrum of adult acute myeloid leukemia associated with core binding factor translocations. Br J Haematol. 2006;135(2):165-73.

17. Prébet $T$, Boissel $N$, Reutenauer $S$, et al. Acute myeloid leukemia with translocation (8;21) or inversion (16) in elderly patients treated with conventional chemotherapy: a collaborative study of the French CBF-AML intergroup. J Clin Oncol. 2009;27(28):4747-53.

18. Vasu S, Kohlschmidt J, Mrózek K, et al. Ten-year outcome of patients not treated with allogeneic transplantation in first complete remission. Blood Adv. 2018;2(13):1645-50.

19. Burd A, Levine RL, Ruppert AS, et al. Precision medicine treatment in acute myeloid leukemia using prospective genomic profiling: feasibility and preliminary efficacy of the Beat AML Master Trial. Nat Med. 2020:26(12):1852-8

20. Eisfeld A-K, Mrózek K, Kohlschmidt J, et al. The mutational oncoprint of recurrent cytogenetic abnormalities in adult patients with de novo acute myeloid leukemia. Leukemia. 2017;31 (10):2211-8.

21. Baer MR, George SL, Caligiuri MA, et al. Low-dose interleukin-2 immunotherapy does not improve outcome of patients age 60 years and older with acute myeloid leukemia in first complete remission: cancer and Leukemia Group B study 9720. J Clin Oncol. 2008;26(30):4934-9.

22. Baer MR, George SL, Sanford BL, et al. Escalation of daunorubicin and addition of etoposidein the ADE regimen in acute myeloid leukemia patients aged 60 years and older: Cancer and Leukemia Group B Study 9720. Leukemia. 2011;25(5):800-7.

23. Marcucci G, Moser B, Blum W, et al. A phase III randomized trial of intensive induction and consolidation chemotherapy \pm oblimersen, a pro-apoptotic BCl-2 antisense oligonucleotide in untreated acute myeloid leukemia patients $>60$ years old. J Clin Oncol. 2007:25:360 (abstract 7012).

24. Mayer RJ, Davis RB, Schiffer CA, et al. Intensive postremission chemotherapy in adults with acute myeloid leukemia. N Engl J Med. 1994;331(14):896-903.

25. Stone RM, Berg DT, George SL, et al. Granulocyte-macrophage colonystimulating factor after initial chemotherapy for elderly patients with primary acute myelogenous leukemia. Cancer and Leukemia Group B. N Engl J Med. 1995;332(25):1671-7.

26. Farag SS, George SL, Lee EJ, et al. Postremission therapy with low-dose interleukin 2 with or without intermediate pulse dose interleukin 2 therapy is well tolerated in elderly patients with acute myeloid leukemia: Cancer and Leukemia Group B study 9420. Clin Cancer Res. 2002;8(9):2812-9.

27. Attar EC, Johnson JL, Amrein PC, et al. Bortezomib added to daunorubicin and cytarabine during induction therapy and to intermediate-dose cytarabine for consolidation in patients with previously untreated acute myeloid leukemia age 60 to 75 years: CALGB (Alliance) study 10502. J Clin Oncol. 2013;31(7):923-9.
28. Yin J, LePlant $B, \cup y G L$, et al. Evaluation of event-free survival as a robust end point in untreated acute myeloid leukemia (Alliance A151614). Blood Adv. 2019;3(11):1714-21.

29. Uy GL, Mandrekar SJ, Laumann K, et al. A phase 2 study incorporating sorafenib into the chemotherapy for older adults with FLT3-mutated acute myeloid leukemia: CALGB 11001. Blood Adv. 2017;1 (5):331-40.

30. Schiffer CA. Intensive post remission therapy of acute myeloid leukemia (AML) with cytoxan/etoposide (CYNP16) and diazaquone/mitoxantrone (AZQ/MITO). Blood. 1991;78(suppl):460 (abstract 1829).

31. Mrózek K, Carroll AJ, Maharry K, et al. Central review of cytogenetics is necessary for cooperative group correlative and clinical studies of adult acute leukemia: the Cancer and Leukemia Group B experience. Int J Oncol. 2008;33(2):239-44.

32. Kroll KW, Eisfeld A-K, Lozanski A, et al. MuCor: mutation aggregation and correlation. Bioinformatics. 2016;32(10):1557-8.

33. Marcucci G, Maharry K, Radmacher MD, et al. Prognostic significance of, and gene and microRNA expression signatures associated with, CEBPA mutations in cytogenetically normal acute myeloid leukemia with highrisk molecular features: a Cancer and Leukemia Group B study. J Clin Oncol. 2008:26(31):5078-87.

34. Whitman SP, Archer KJ, Baldus C, et al. Absence of the wild-type allele predicts poor prognosis in the adult de novo acute myeloid leukemia with normal cytogenetics and the internal tandem duplication of FLT3: a Cancer and Leukemia Group B study. Cancer Res. 2001;61(19):7233-9.

35. Yamazaki J, Taby R, Vasanthakumar A, et al. Effects of TET2 mutations on DNA methylation in chronic myelomonocytic leukemia. Epigenetics. 2012;7(2):201-7.

36. Shih AH, Jiang Y, Meydan C, et al. Mutational cooperativity linked to combinatorial epigenetic gain of function in acute myeloid leukemia. Cancer Cell. 2015;27(4):502-15.

37. Sinha $S$, Thomas D, Yu L, et al. Mutant WT1 is associated with DNA hypermethylation of PRC2 targets in AML and responds to EZH2 inhibition. Blood. 2015;125(2):316-26.

38. Vittinghoff E, Glidden DV, Shiboski SC, McCulloch CE. Regression methods in biostatistics: linear, logistic, survival and repeated measures models. New York: Springer; 2005.

39. Cancer Genome Atlas Research Network, Ley TJ, Miller C, Ding L, et al. Genomic and epigenomic landscapes of adult de novo myeloid leukemia. N Engl J Med. 2013;368(22):2059-74.

40. Lavallée VP, Baccelli I, Krosl J, et al. The transcriptomic landscape and directed chemical interrogation of MLL-rearranged acute myeloid leukemias. Nat Genet. 2015;47(9):1030-7.

41. Sperr WR, Zach O, Pöll I, et al. Karyotype plus NPM1 mutation status defines a group of elderly patients with AML ( $\geq 60$ years) who benefit from intensive post-induction consolidation therapy. Am J Hematol. 2016;91(12):1239-45.

42. Hoyos M, Nomdedeu JF, Esteve J, et al. Core binding factor acute myeloid leukemia: the impact of age, leukocyte count, molecular findings, and minimal residual disease. Eur J Haematol. 2013;91(3):209-18.

43. Norsworthy KJ, By K, Subramaniam S, et al. FDA approval summary: glasdegib for newly diagnosed acute myeloid leukemia. Clin Cancer Res. 2019;25(20):6021-5.

44. Klepin HD, Geiger AM, Tooze JA, et al. Geriatric assessment predicts survival for older adults receiving induction chemotherapy for acute myelogenous leukemia. Blood. 2013;121(21):4287-94.

45. Klepin HD, Ritchie E, Major-Elechi B, et al. Geriatric assessment among older adults receiving intensive therapy for acute myeloid leukemia: report of CALGB 361006 (Alliance). J Geriatr Oncol. 2020;11 (1):107-13.

46. Walter RB, Othus M, Borthakur G, et al. Prediction of early death after induction therapy for newly diagnosed acute meyloid leukemia with pretreatment risk scores: a novel paradigm for treatment assignment. J Clin Oncol. 2011;29(33):4417-23.

47. Gerstung M, Papaemmanuil E, Martincorena I, et al. Precision oncology for acute myeloid leukemia using a knowledge bank approach. Nat Genet. 2017:49(3):332-40.

48. Krauss AC, Gao X, Li L, et al. FDA approval summary: (daunorubicin and cytarabine) liposome for injection for the treatment of adults with highrisk acute myeloid leukemia. Clin Cancer Res. 2019;25(9):2685-90.

49. Eisfeld A-K, Kohlschmidt J, Mrózek K, et al. Mutation patterns identify adult patients with de novo acute myeloid leukemia aged 60 years or 
older who respond favorable to standard chemotherapy: an analysis of Alliance studies. Leukemia. 2018;32(6):1338-48.

50. Heibligh M, Labussière-Wallet NFE, et al. Prognostic value of genetic alterations in elderly patients with acute myeloid leukemia: a single institution experience. Cancers (Basel). 2019;1 14):570.

51. Amatangelo MD, Quek L, Shih A, et al. Enasidenib induces acute myeloid leukemia cell differentiation to promote clinical response. Blood. 2017;130(6):732-41.

52. McMahon CM, Ferng T, Canaani J, et al. Clonal selection with RAS pathway activation mediates secondary clinical resistance to selective FLT3 inhibition in acute myeloid leukemia. Cancer Discov. 2019;9(8):1050-63.

53. Juliusson G, Jädersten $M$, Deneberg $S$, et al. The prognostic impact of FLT3-ITD and NPM1 mutation in adult AML is age-dependent in the population-based setting. Blood Adv. 2020;4(6):1094-101.

54. Medeiros BC, Satram-Hoang S, Hurst D, et al. Big data analysis of treatment patterns and outcomes among elderly acute myeloid leukemia patietns in the United States. Ann Hematol. 2015;94(7):1127-38.

55. Ma E, Bonthapally V, Chawla A, et al. An evaluation of treatment pattern and outcomes in elderly patients newly daignosed with acute meyloid leukemia: a retrospective analysis of electronic medical records from US community oncology practices. Clin Lymphoma Myeloma Leuk. 2016;16(11):625-36.

56. Zeidan AM, Podoltsev NA, Wang X, et al. Temporal patterns and predictors of receiving no active treatment among older patients with acute myeloid leukemiai $n$ the United States: a population-level analysis. Cancer. 2019;125(23):4241-51.

57. Walter RB, Ofran Y, Wierzbowska A, et al. Measurable residual disease as a biomarker in acute myeloid leukemia: theoretical and pratical considerations. Leukemia. 2021; March 23: Online ahead of print.

58. Dombret H, Seymour JF, Butryn A, et al. International phase 3 study of azacitidine vs conventional care regimens in older patients with newly diagnosed AML with >30\% blasts. Blood. 2015;126(3):291-9.

\section{Publisher's Note}

Springer Nature remains neutral with regard to jurisdictional claims in published maps and institutional affiliations. 